\title{
Needles and bark of Picea abies (L.) H. Karst and Picea omorika (Pančić) Purk. as bioindicators of environmental quality
}

\author{
Agnieszka Parzych ${ }^{1} \bowtie$, Sergej Mochnacký2, Zbigniew Sobisz ${ }^{1}$, Nora Polláková ${ }^{3}$, \\ Vladimír Šimanský3 \\ ${ }^{1}$ Pomeranian University in Slupsk, Institute of Biology and Environmental Protection, Arciszewskiego 22 A, \\ 76-200 Słupsk, Poland, e-mail: agnieszka.parzych@apsl.edu.pl \\ 2 P.J. Šafárik University in Košice, Botanic Garden, Slovak Republic \\ ${ }^{3}$ Slovak University of Agriculture in Nitra, Department of Soil Science and Geology, Tr. A. Hlinku 2, 94976 Nitra, \\ Slovak Republic
}

\section{Abstract}

The paper presents the results of the research on the accumulation of nutrients and heavy metals in needles and bark of Picea abies and Picea omorika. In this research, the age of the needles and the content of the examined components in the soil were taken into account. The research was conducted within the area of the forest at the University botanic garden in Košice (Slovakia). The little acidification of the soil that was found under the spruce crowns slightly changed with the depth $(0.0-0.2 \mathrm{~m}, 0.2-0.4 \mathrm{~m}, 0.4-0.6 \mathrm{~m})$. Under the stand of $P$. abies, a lower content of organic matter was demonstrated, than under the trees of $P$. omorika. The tested soil samples were low in nitrogen, phosphorus and calcium, and sufficiently rich in potassium and magnesium. The spruce needles were dominated by macroelements, and their concentrations varied depending on age and species. Both P. abies and P. omorika needles were acidic, with 1-year-old needles showing higher acidity. Low nitrogen content in the needles of the studied spruce was found, and the N:P ratio did not exceed 3.5. Statistically significant differences were found in the content of $\mathrm{N}, \mathrm{K}, \mathrm{Ca}, \mathrm{Zn}, \mathrm{Mn}, \mathrm{Fe}, \mathrm{Ni}, \mathrm{Cu}$ and $\mathrm{Cd}$ in 1-year-old needles and pH, N, P, Ca, Zn, Mn, Fe, Ni, Cu and Cd in 2-yearold needles of spruces. The results also indicate that the bark of the studied spruce is acidic, with $\mathrm{pH}$ values of 4.70 (P. abies) and 4.15 (P. omorika). The P. abies bark accumulates higher amounts of $\mathrm{Mg}, \mathrm{Ca}, \mathrm{Ni}, \mathrm{Cu}$ and $\mathrm{Mn}$, and the $P$. omorika bark accumulates more N, $\mathrm{P}, \mathrm{K}, \mathrm{Zn}, \mathrm{Fe}$ and $\mathrm{Cd}$. The research indicates that both spruce species barks are suitable for comparative studies on bioindication of environment quality.

\section{KEY WORDS}

accumulation, heavy metals, needle age class, nutrients, N:P, K:Ca, spruce 


\section{INTRODUCTION}

Picea is a genus of evergreen trees from the Pinaceae family, which includes about 35 species. Their occurrence is mainly limited to the northern hemisphere (Boratyńska 2007). Picea genus are natural components of forest communities, important production species in economic forests (Bennet and Buchen 1995), and because of their decorative qualities, also the frequent components of dendroflora of many botanical gardens. Spruces are large trees, about 20-60 $\mathrm{m}$ in height. Picea abies, the Norway spruce, is a species of spruce native to Northern, Central and Eastern Europe. Serbian spruce, Picea omorika is an ancient endemic species found in natural communities in Central Europe (Bugała 2000). Now, atmospheric and soil pollution constitutes a major problem especially in urban environment (Parzych and Jonczak 2014; Świercz et al. 2014; Chen et al. 2016; Zhao et al. 2016). Monitoring the quality of the environment using trees is widely accepted as a reliable and inexpensive way of obtaining information about the state of the environment. The main advantage of this monitoring research is an opportunity to make long-term comparisons. A good bioindicator in the case of contact with harmful substances shows an increased concentration of elements in its tissues. The monitoring studies use species of deciduous and coniferous trees (Piczak et al. 2003; Parzych et al. 2017). In addition to Pinus species, Picea genus (Wyttenbach et al. 1995a, b; Wyttenbach and Tobler 2000; Mankovská 2001; Silkina and Vinokurova 2009) trees are also used in monitoring studies. The chemical composition of needles and tree bark reflect the quality of the environment (Parzych et al. 2017). The accumulation of nutrients and heavy metals in needles and barks of trees has drawn considerable attention as a possible indicator of inorganic pollution of the environment, as plants respond directly to the state of the soil and air (Divan et al. 2009; Serbula et al. 2013; Świercz et al. 2014). According to Augusto et al. (2002), the species of coniferous trees absorb more components than leafy trees from the air due to a larger surface of the needles. Spruces keep its needles for several years. It is well known that elemental concentrations in needles change with the needle age class (Mahendrappa et al. 1986; Cape et al. 1990).
The aim of the research was to compare the accumulation of N, P, K, Mg, Ca, Cu, Ni, Mn, Fe, Zn and Cd in the needles and bark of Picea abies (L.) H. Karst and Picea omorika (Pančić) Purk. In the research, the age of the needles and the content of the examined components in the soil were taken into account.

\section{MATERIAL AND METHOdS}

\section{Research area}

The research was conducted in June 2015 within the area of the forest at the University botanic garden in Košice (Slovakia). The garden (30 ha) is situated at an altitude of 218 to $370 \mathrm{~m}$ a.s.l. The upper part of the garden is covered by the so-called natural forest which is represented by the forest stands planted in the time of the Botanical Garden foundation, consequently not maintained. Particularly, they are the plantations of both native and introduced woody species, namely: Acer platanoides L., Robinia pseudoacacia L., Quercus petraea (Mattusch.) Liebl., Cerasus avium L., Tilia platyphyllos Scop. and Ulmus laevis Pall. (Kebel and Koštálik 2011). The vital part of the Park area is covered by forest communities with a participation of the species of Picea abies and Picea omorika. The tree stands selected for the research are characterized the average breast height from $84.0 \mathrm{~cm}$ (Picea omorika) to $130.0 \mathrm{~cm}$ (Picea abies) (Tab. 1). The tree stands grow in the shallow soils of Cambisol type (Mochnacký 2001; Kebel and Koštálik 2011). The study area is characterized with an average annual precipitation of about $643 \mathrm{~mm}$ and average annual air temperature at the level of $8.4^{\circ} \mathrm{C}$.

Table 1. Characteristic of Picea species

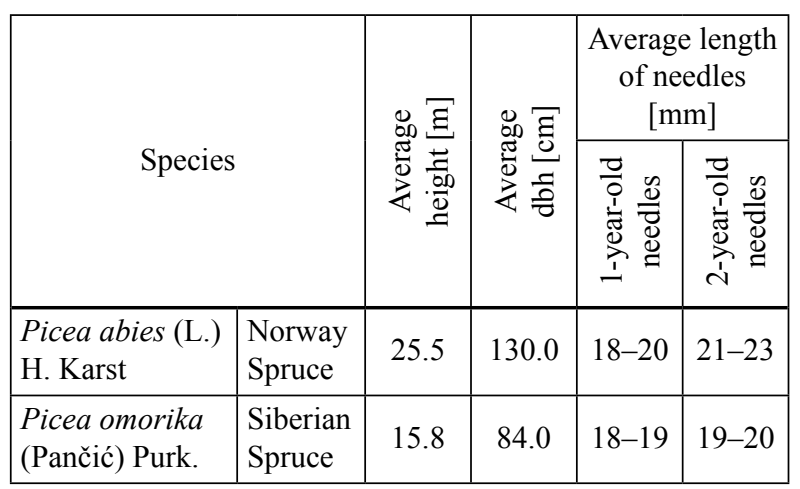




\section{Sampling and analysis of soil}

Under the crowns of the 5 trees of each of the two species of Picea, soils samples were taken for physical and chemical analysis from a depth of $0-0.2 \mathrm{~m}$, $0.2-0.4 \mathrm{~m}$ and $0.4-0.6 \mathrm{~m}$. The samples were dried $\left(65^{\circ} \mathrm{C}\right)$ in the dryer with forced air circulation and milled into powder (laboratory grinder A11, IKA). In the soil, the organic matter content was marked by the use of the method of roasting in a muffle furnace at a temperature of $550^{\circ} \mathrm{C}$ and $\mathrm{pH}$ in a water solution by a potentiometer method (pH-metr CPI 551, Elmetron, Poland). In order to determine the presence of nitrogen and phosphorus, the samples of soil were digested in $98 \% \mathrm{H}_{2} \mathrm{SO}_{4}$ and $30 \% \mathrm{H}_{2} \mathrm{O}_{2}$. Nitrogen was determined using the Kjeldahl method (automatic distiller $\mathrm{K}$ - 350, Büchi), and phosphorus the molybdate method (U - 5100, Hitachi, Japan). In order to determine the metallic elements, the samples of the soil were digested in the solutions of $65 \% \mathrm{HNO}_{3}$ and $30 \% \mathrm{H}_{2} \mathrm{O}_{2}$. K, $\mathrm{Mg}, \mathrm{Ca}, \mathrm{Zn}, \mathrm{Ni}, \mathrm{Cu}, \mathrm{Mn}, \mathrm{Fe}$ and $\mathrm{Cd}$ content was determined by the method of absorption atomic spectrometry (AAS) using the Aanalyst 300 instrument (Perkin Elmer, USA). The tests were carried out following the original standards of Merck $\left(\mathrm{KGaA}, 1 \mathrm{~g} / 1 \mathrm{dm}^{-3}\right)$. The metals were determined with the following wave lengths: $\mathrm{K}-769.9 \mathrm{~nm}, \mathrm{Ca}-422.7 \mathrm{~nm}, \mathrm{Mg}-202.6 \mathrm{~nm}$, $\mathrm{Zn}-213.9 \mathrm{~nm}, \mathrm{Cu}-324.8 \mathrm{~nm}, \mathrm{Ni}-232.0 \mathrm{~nm}, \mathrm{Fe}$ $-248.3 \mathrm{~nm}, \mathrm{Mn}-279.5 \mathrm{~nm}$ and $\mathrm{Cd}-228.8 \mathrm{~nm}$.

\section{Sampling and analysis of needles and bark}

5 trees each of the 2 species of Picea (Picea abies, Picea omorika) were earmarked for the study (Tab. 1). From each tree, samples of needles from the seventh whorl weighing $10-20 \mathrm{~g}$ were taken for the tests separating 1 year old needles from 2 years old ones (Rautio et al. 2010). In the laboratory, the needles were hand washed in deionized water in order to remove any particulate matter. From the trunks of the trees, at the breast height $(1.2-1.3 \mathrm{~m})$ samples of external layer of the bark were taken. The bark and the needles were dried (at $65^{\circ} \mathrm{C}$ ) and were homogenized (A11, IKA). In the samples of the needles and the bark, the $\mathrm{pH}$ was determined in a water solution by means of the potentiometer method. In order to determine $\mathrm{N}, \mathrm{P}, \mathrm{K}, \mathrm{Mg}, \mathrm{Ca}, \mathrm{Zn}, \mathrm{Cu}, \mathrm{Ni}, \mathrm{Fe}$, $\mathrm{Mn}$ and $\mathrm{Cd}$, needles and bark samples were digested in the same mixtures as for soil samples. The same meth- ods were used for the determination of chemical elements as for the soil samples.

\section{Data elaboration}

The distribution of physicochemical properties of soil samples and the content of $\mathrm{N}, \mathrm{P}, \mathrm{K}, \mathrm{Ca}, \mathrm{Mg}, \mathrm{Zn}, \mathrm{Cu}$, $\mathrm{Ni}, \mathrm{Mn}, \mathrm{Fe}$ and $\mathrm{Cd}$ in needles and bark of Picea abies and Picea omorika was tested with the Shapiro-Wilk test. The statistical significance of the properties of soil, needle and bark samples between the tested species was compared using the non-parametric Mann-Whitney $\mathrm{U}$ test. The N:P and $\mathrm{K}: \mathrm{Ca}$ ratios in the spruce needles were compared using the Kruskal-Wallis test results. In order to ensure quality control of the obtained results, a certified reference material analysis of the plant sample (CRM 060) was carried out. The obtained results did not exceed the error limits $\pm 3 \%$.

\section{Results AND DISCUSSION}

\section{Physicochemical properties of soil under trees}

Soil samples collected under the spruce crowns showed different properties depending on the species. On both the stands of Picea abies and Picea omorika, little soil acidification was found under the tree crowns $(\mathrm{pH}=6.0-5.7$ and $\mathrm{pH}=5.9-5.2$, respectively), which changed slightly with depth (Tab. 2). Stronger acidification of the soil was observed under the crowns of $P$. omorika, which indicates that in this case, bigger quantity of acid components are leached out of the spruce crowns by precipitation than in the case of P. abies (Jóźwiak and Kozłowski 2008). According to Obmiński (1977), spruces grow best on soils with $\mathrm{pH}$ in the range of 5.3-6.0. Acidification of soil under coniferous stands is a fairly common phenomenon, observed by Kowalkowski and Kopron (2006), Jonczak and Parzych (2015). It has a significant impact on the bioavailability of many nutrients and heavy metals for the root system of trees.

In the soil under the spruce stand, the content of organic matter ranged from $17.3 \%$ in the surface layer to $9.0 \%$ at a depth of $0.4-0.6 \mathrm{~m}$ (P. omorika) and respectively from $13.4 \%$ to $7.2 \%$ under the crowns of $P$. abies. With depth, smaller quantities of organic matter were observed (Tab. 2). The sources of organic matter are dead plant remains, which constitute an important link in the circulation of matter and the flow of energy. Increased 
content of organic matter in the top soil layers is the result of a year-round, systematic inflow of organic precipitation (Parzych and Trojanowski 2009), decomposition rate of which depends on the species and qualitative characteristics of the stand (Jonczak et al. 2015). Lower content of organic matter in the soil under the stand of P. abies indicates that the processes of mineralization of organic precipitation under the crowns of this species occur more efficiently than under the trees of $P$. omorika. Soil organic matter strongly affects the physical and chemical properties of soils (Jonczak and Parzych 2016), and the most favourable conditions for the decomposition of organic matter occur in soils rich in biogenic elements with a reaction similar to neutral (Bednarek et al. 2005).

\section{Macro- and microelements content in soil under spruces}

The content of macro- and microelements in the soil under the spruce stand varied depending on the species and depth. The largest amounts of macroelements occurred in the top layers of the studied soil and slightly changed with depth. The nitrogen content was maintained at the level of 1400 to $2520 \mathrm{mg} \cdot \mathrm{kg}^{-1}$ (P. abies) and from 2530 to $3478 \mathrm{mg} \cdot \mathrm{kg}^{-1}$ (P. omorika), phosphorus from 657.9 to $737.0 \mathrm{mg} \cdot \mathrm{kg}^{-1}$ (P. abies) and from 594.7 to $655.2 \mathrm{mgkg}^{-1}$ (P. omorika), and potassium levels varied from 1652.7 to $2078.8 \mathrm{mg} \cdot \mathrm{kg}^{-1}$ (P. abies) and from 1975.0 to $2101.2 \mathrm{mg} \cdot \mathrm{kg}^{-1}$ under the trees of P. omorika (Tab. 2). Magnesium was found in the studied soils in much larger amounts. Its concentrations ranged from 4719.3 to $5383.4 \mathrm{mg} \cdot \mathrm{kg}^{-1}$ under the P. abies stand and from 5310.0 to $5895.0 \mathrm{mg} \cdot \mathrm{kg}^{-1}$ under the $P$. omorika trees. The calcium content was maintained at the level of 202.7-641.7 $\mathrm{mg} \cdot \mathrm{kg}^{-1}$ (P. abies) and 198.7-303.8 $\mathrm{mgkg}^{-1}$ (P. omorika) depending on the depth. Among the heavy metals determined in the soil samples, iron prevailed, with higher values under the stand of P. omorika (36406.7-41903.3 $\mathrm{mgkg}^{-1}$ ), than under P. abies (26175-31341.7 $\left.\mathrm{mg} \cdot \mathrm{kg}^{-1}\right)$. A similar situation was found for copper (29.0-33.5 $\left.\mathrm{mg} \cdot \mathrm{kg}^{-1}\right)$, nickel (44.8-101.8 $\mathrm{mg}^{-1} \mathrm{~kg}^{-1}$ ) and zinc (94.7-110.1 $\mathrm{mg}^{-1} \mathrm{~kg}^{-1}$ ), and the reverse for manganese. Higher Mn concentrations occurred in the soil under $P$. abies tree stand (526.5-579.2 $\left.\mathrm{mgkg}^{-1}\right)$, than under the $P$. omorika trees

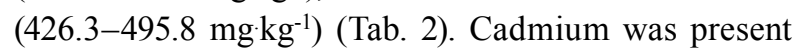
in trace amounts, taking values from 0.1 to $0.9 \mathrm{mg} \cdot \mathrm{kg}^{-1}$ (P. omorika) and from 0.5 to $1.4 \mathrm{mg} \mathrm{kg}^{-1}$ (P. abies).
Table 2. The physicochemical properties of the soil $( \pm \mathrm{SD})$ taken under trees of Picea species with U Mann Whitney test results

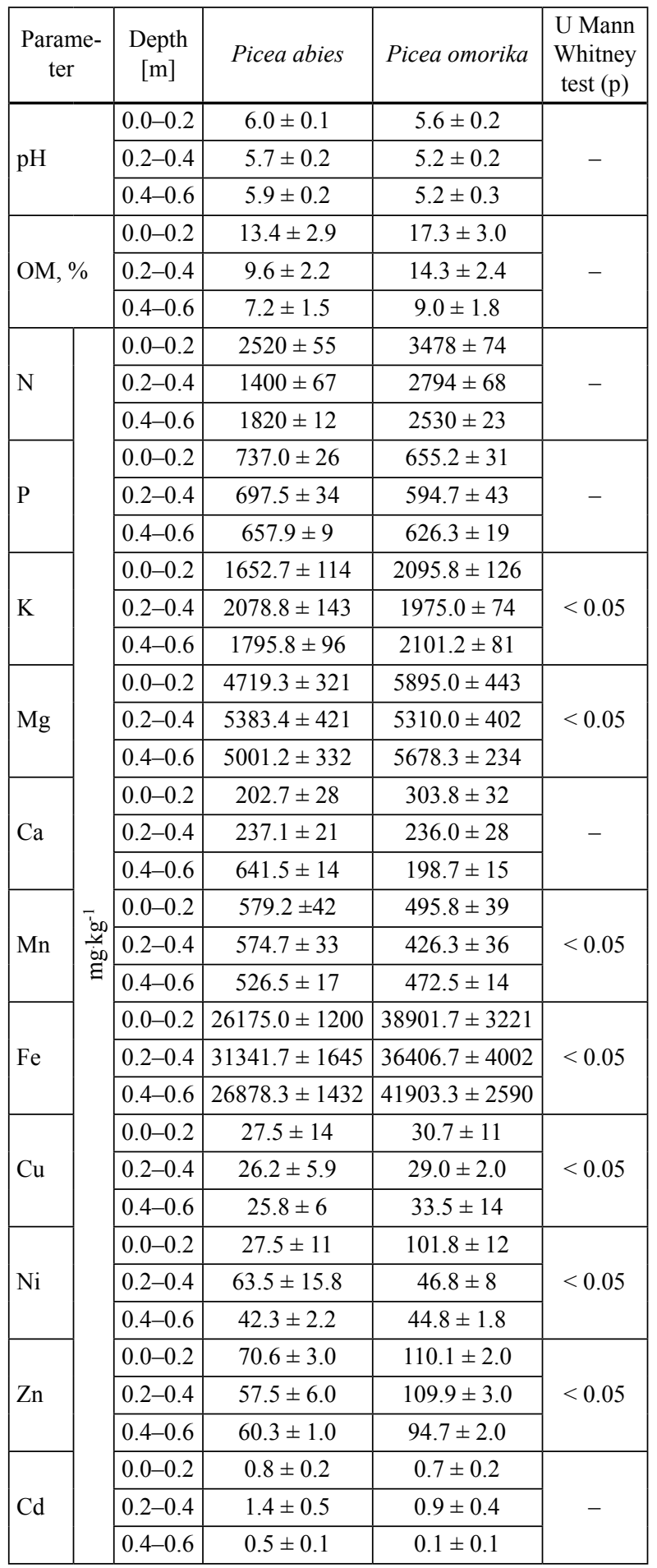

Note: OM - organic matter, SD - standard deviation $\mathrm{p}-$ level of significance 
Table 3. Nutrients and heavy metals $\left(\mathrm{mg}^{\mathrm{kg}} \mathrm{kg}^{-1}\right)$ content and $\mathrm{pH}$ in needles of Picea species with U Mann Whitney test results

\begin{tabular}{|c|c|c|c|c|}
\hline $\begin{array}{l}\text { Para- } \\
\text { meter }\end{array}$ & $\begin{array}{l}\text { Age of } \\
\text { needles } \\
\text { (years) }\end{array}$ & $\begin{array}{c}\text { Picea } \\
\text { abies }\end{array}$ & $\begin{array}{c}\text { Picea } \\
\text { omorica }\end{array}$ & $\begin{array}{c}\text { U Mann } \\
\text { Whitney test } \\
\text { (p-level) }\end{array}$ \\
\hline \multirow{2}{*}{$\mathrm{pH}$} & 1 & $4.20 \pm 0.2$ & $4.26 \pm 0.3$ & - \\
\hline & 2 & $4.23 \pm 0.2$ & $4.55 \pm 0.2$ & $<0.05$ \\
\hline \multirow{2}{*}{$\mathrm{N}$} & 1 & $6020 \pm 140$ & $6720 \pm 280$ & $<0.05$ \\
\hline & 2 & $5880 \pm 741$ & $3793 \pm 153$ & $<0.05$ \\
\hline \multirow{2}{*}{$\mathrm{P}$} & 1 & $2233 \pm 119$ & $2067 \pm 45$ & - \\
\hline & 2 & $2022 \pm 147$ & $1545 \pm 34$ & $<0.05$ \\
\hline \multirow{2}{*}{$\mathrm{K}$} & 1 & $4766 \pm 165$ & $4277 \pm 112$ & $<0.05$ \\
\hline & 2 & $5443 \pm 64$ & $4559 \pm 208$ & - \\
\hline \multirow{2}{*}{$\mathrm{Mg}$} & 1 & $1160 \pm 90$ & $1715 \pm 95$ & - \\
\hline & 2 & $1675 \pm 127$ & $1432 \pm 14$ & - \\
\hline \multirow{2}{*}{$\mathrm{Ca}$} & 1 & $2346 \pm 90$ & $4182 \pm 95$ & $<0.05$ \\
\hline & 2 & $2666 \pm 511$ & $5742 \pm 67$ & $<0.05$ \\
\hline \multirow{2}{*}{$\mathrm{Zn}$} & 1 & $32.8 \pm 0.7$ & $58.4 \pm 0.6$ & $<0.05$ \\
\hline & 2 & $43.3 \pm 2.2$ & $78.5 \pm 0.7$ & $<0.05$ \\
\hline \multirow{2}{*}{$\mathrm{Ni}$} & 1 & $13.5 \pm 0.6$ & $26.5 \pm 1.4$ & $<0.05$ \\
\hline & 2 & $12.5 \pm 2.0$ & $25.0 \pm 1.9$ & $<0.05$ \\
\hline \multirow{2}{*}{$\mathrm{Cu}$} & 1 & $3.5 \pm 0.1$ & $6.2 \pm 0.5$ & $<0.05$ \\
\hline & 2 & $6.4 \pm 0.6$ & $8.7 \pm 0.7$ & $<0.05$ \\
\hline \multirow{2}{*}{ Mn } & 1 & $129.0 \pm 5.2$ & $28.0 \pm 3.3$ & $<0.05$ \\
\hline & 2 & $161.3 \pm 12.7$ & $48.4 \pm 5.0$ & $<0.05$ \\
\hline \multirow{2}{*}{$\mathrm{Fe}$} & 1 & $113.7 \pm 14.2$ & $122.7 \pm 5.2$ & $<0.05$ \\
\hline & 2 & $189.2 \pm 5.6$ & $223.9 \pm 3.6$ & $<0.05$ \\
\hline \multirow{2}{*}{$\mathrm{Cd}$} & 1 & \pm 0.6 & $0.1 \pm 0.1$ & $<0.05$ \\
\hline & 2 & $1.3 \pm 0.4$ & $0.2 \pm 0.3$ & $<0.05$ \\
\hline
\end{tabular}

Analysing the physicochemical properties of soil samples collected under the crowns of Picea abies and Picea omorika, statistically significant differences were found in the concentration of $\mathrm{K}, \mathrm{Mg}, \mathrm{Mn}, \mathrm{Fe}, \mathrm{Cu}, \mathrm{Ni}$ and $\mathrm{Zn}$ (Tab. 2). These differences resulted from the impact of tree crowns on soil properties (Jonczak and Parzych 2012; Polláková et al. 2015). Under the stand of P. omori$k a$, higher concentrations of $\mathrm{N}, \mathrm{K}, \mathrm{Ca}, \mathrm{Mg}, \mathrm{Fe}, \mathrm{Cu}$ and $\mathrm{Zn}$ were found than in the case of $P$. abies. The soil samples tested were not very rich in nitrogen, phosphorus and calcium, and sufficiently rich in potassium and magnesium, which influenced the content of macroelements in needles (Tab. 3). Nitrogen is a very important nutrient; however, it often occurs in the soil in insufficient quantities to meet the nutritional needs of plants (Gonet 2007) and constitutes an important factor limiting the growth and development of plants (Oren et al. 2001). The acid reaction of the studied soils (Tab. 2) can be an important factor limiting the bioavailability of phosphorus for the root system of trees (Achat et al. 2013). The phosphorus compounds are most available to the plants at $\mathrm{pH}$ from 6.0 to 10.0 , whereas calcium and magnesium at $\mathrm{pH} 6.5-8.5$. Spruce trees have much higher soil requirements than pine trees with respect to moisture and soil abundance. They grow well on clayey-sandy and sandy-loamy soils. The soil's abundance in nutrients determines its fertility and productivity (Bednarek et al. 2005).

The occurrence of heavy metals in the soil is related to their content in the parent rock and the nature of soilforming processes (Kabata-Pendias and Pendias 1999). The concentration of heavy metals in the top layer of soil is significantly affected by the precipitation of atmospheric dust, which is the carrier of many pollutants, especially in areas under the influence of anthropogenic factors (Rapport 2016). The metals deposited on the top layer of soil are bound by a solid soil phase, collected by organisms and washed by precipitation into deeper soil layers (Parzych and Jonczak 2014). The amount of bioavailable forms of heavy metals is closely dependent on the $\mathrm{pH}$ of the soil and on the organic matter content (Päivärinta and Lodenius 1994; Parzych and Jonczak 2013). Increase in mobility of $\mathrm{Zn}, \mathrm{Mn}$ and $\mathrm{Cd}$ is most effective with $\mathrm{pH}=6, \mathrm{Fe}$ at $\mathrm{pH}=4$, while $\mathrm{Ni}$ and $\mathrm{Cu}$ at $\mathrm{pH}=5.5$ (Alloway 1995). The increase of Fe content in the soil with the depth under the $P$. abies $(0.2-0.4 \mathrm{~m})$ and $P$. omorika $(0.4-0.6 \mathrm{~m})$ tree stands is the result of increased soil acidity in these layers compared to the $0.0-0.2 \mathrm{~m}$ layer. Acidification causes the soluble forms of iron to be washed into the deeper soil layers. A similar phenomenon was observed by Parzych and Jonczak (2013) under the tree stand of P. sylvestris in the Słowiński National Park (northern Poland).

\section{Physicochemical properties of spruce needles}

Both the needles of Picea abies and Picea omorika were characterized by acid reaction, with higher acidity showed by 1 -year-old needles than by 2 -year old ones (Tab. 3). The results of many studies confirm that the acidic reaction of needles is characteristic of various species of conifers (Świercz 2006; Parzych et al. 2017). 
The studied components of the spruce needles were dominated by macroelements and their concentrations varied depending on the species and the age of the needles. In samples of 1-year-old needles, $\mathrm{N}$ and $\mathrm{P}$ dominated in case of both spruce species, while $\mathrm{Mg}$ in the case of $P$. omorika. The older (2-year-old) needles have higher concentrations of $\mathrm{K}, \mathrm{Ca},(P$. abies and $P$. omorika), as well as $\mathrm{Mg}(P$. abies). Nitrogen predominated in most samples except for the 2-year-old $P$. omorika needles, in which calcium was found in greater amounts. The $\mathrm{N}$ content remained at the level of $5880-6020 \mathrm{mg} \cdot \mathrm{kg}^{-1}$ (P. abies) and 3793-6720 mg.kg-1 (P. omorika) (Tab. 3). Comparing the above results with the average supply of plants with nitrogen (13000-31000 mg kg ${ }^{-1}$, Ostrowska and Porębska 2002), low concentrations of this component in the needles of the studied spruces were found. The reason for the deficiency of $\mathrm{N}$ in the spruce needles may be slow decomposition of its organic litterfall Schmidt-Vogt (1977) limiting the inflow of additional nitrogen compounds to the soil (Parzych and Trojanowski 2011). A slightly different situation was observed in the case of phosphorus. Both P. abies (2022-2233 $\left.\mathrm{mgkg}^{-1}\right)$, as well as $P$. omorika $\left(1545-2067 \mathrm{mg} \cdot \mathrm{kg}^{-1}\right)$ needles were characterized by sufficient phosphorus content. Nitrogen deficiency is reflected in the N:P ratio in needles (Fig. 1). The N:P ratio took average values from 2.7 in 1-year-old needles to 2.9 in 2-year-old $P$. abies needles and from 3.3 to 2.5 in P. omorika needles, respectively. In all the samples, the N:P ratio was low and did not exceed 3.5. According to Zhiguo et al. (2007), the maximum plant growth occurs at N:P close to 9.5, and Güsewell (2004) believes that N:P in plants can take values from 10 to 20 .

The needles of the studied spruces accumulated adequate amounts of potassium (4766-5443 mg kg-1 P. abies and $4277-4559 \mathrm{mg} \cdot \mathrm{kg}^{-1}$ P. omorika). The obtained results indicate good supply of $P$. abies and $P$. omorika needles in $\mathrm{P}$ and $\mathrm{K}$. According to Swan (1972), the symptoms of phosphorus deficiency appear when $P$ concentrations in the dry matter of spruce needles are below $800-1000 \mathrm{mg} \cdot \mathrm{kg}^{-1}$, and potassium below $4000 \mathrm{mgkg}^{-1}$. The results of the research conducted by Roberntz and Linder (1999) confirm that the 1-year-old needles of $P$. abies are usually richer in nitrogen and phosphorus and poorer in calcium than the older needles. 1-year-old needles of $P$. abies tested by Mankovská (2001) accumulated larger amounts of $\mathrm{N}$
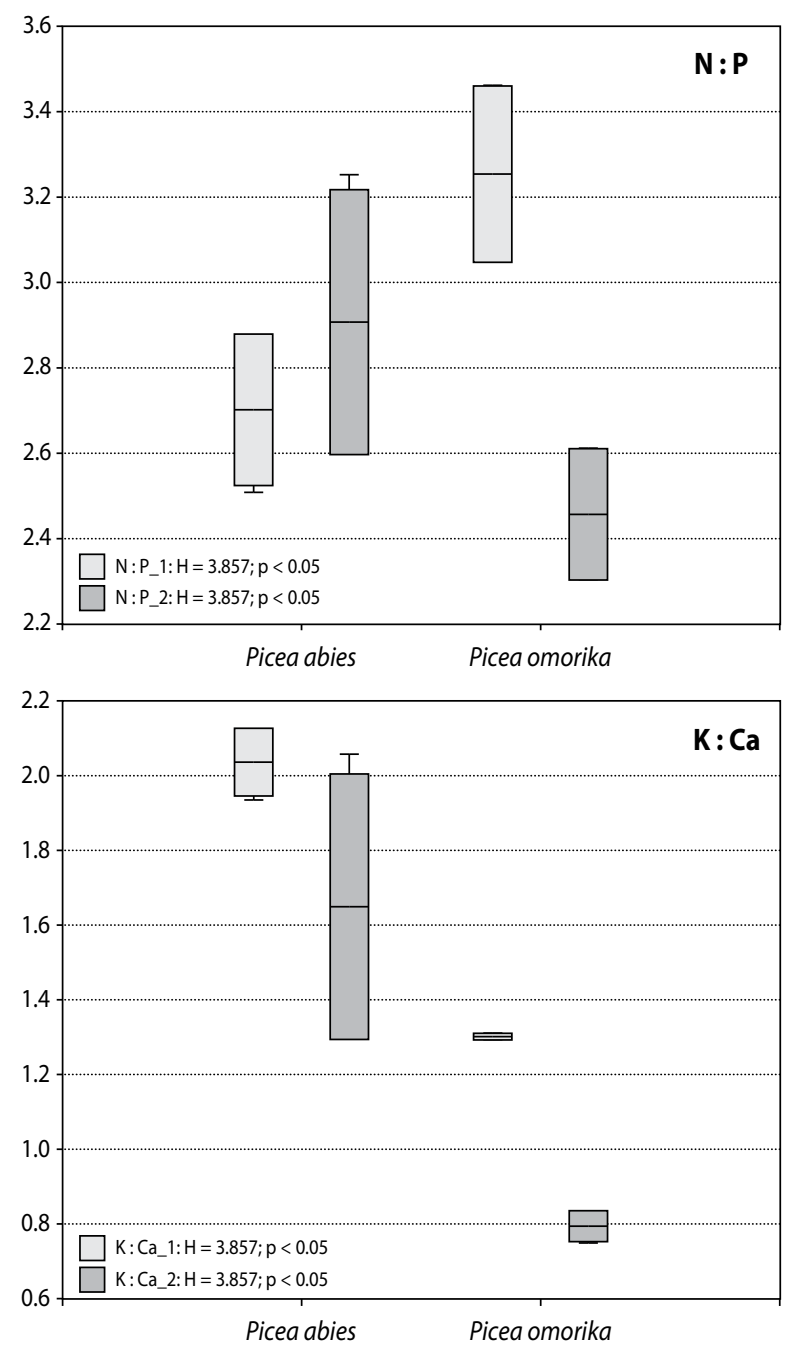

Figure 1. $\mathrm{N}: \mathrm{P}$ and $\mathrm{K}: \mathrm{Ca}$ ratios in 1-year $\left(\mathrm{N}: \mathrm{P} \_1, \mathrm{~K}: \mathrm{Ca} \_1\right)$ and 2-year (N:P_2, K:Ca_2) old needles of spruces with a Kruskal-Wallis test results

and $\mathrm{K}$ (12744 $\left.\mathrm{mg} \cdot \mathrm{kg}^{-1} \mathrm{~N}, 6127 \mathrm{mg} \cdot \mathrm{kg}^{-1} \mathrm{~K}\right)$, comparable amounts of $\mathrm{Ca}\left(2891 \mathrm{mg} \cdot \mathrm{kg}^{-1}\right)$ and lower contents of $\mathrm{P}$ $\left(1174 \mathrm{mgkg}^{-1} \mathrm{P}\right)$ than older needles. The results obtained by Wyttenbach and Tobler (1988) indicate that Norway spruce needles, depending on environmental conditions, accumulate $930-1222 \mathrm{mg} \cdot \mathrm{kg}^{-1} \mathrm{P}, 4321-5197 \mathrm{mg}^{-1} \mathrm{~kg}^{-1} \mathrm{~K}$, 736-981 mg.kg-1 $\mathrm{Mg}$ and 6664-10106 mg.kg-1 Ca. In the case of calcium, the decisive factor for its content in needles is the age of the stand (Fober 1993; Parzych 2018). Good supply of needles in $\mathrm{K}$ and $\mathrm{Ca}$ is reflected in the correct value of the ratio $\mathrm{K}: \mathrm{Ca}$ (Commission Advice Forest Fertilization 1990). In P. abies needles, the ratio $\mathrm{K}:$ Ca takes the values from 2.0 to 1.6 , and in P. omorika, 
it was lower and ranged from 1.3 to 0.8 depending on the age of the needles (Fig. 1).

The content of heavy metals in needles was also dependent on the age and species of spruce. The 1-yearold needles were characterized by higher $\mathrm{Ni}$ concentration than the older needles, and 2-year-old needles showed a higher content of $\mathrm{Zn}, \mathrm{Cu}, \mathrm{Mn}, \mathrm{Fe}$ and $\mathrm{Cd}$ than 1 -year old ones. The concentration of zinc ranged from $32.8-43.3 \mathrm{mg} \cdot \mathrm{kg}^{-1}$ in $P$. abies and $58.4-78.5 \mathrm{mg} \cdot \mathrm{kg}^{-1}$ in $P$. omorika, nickel $13.5-12.5 \mathrm{mg} \cdot \mathrm{kg}^{-1}$ (P. abies) and 26.5-25.0 mg. $\mathrm{kg}^{-1}$ (P. omorika), copper $3.5-6.4 \mathrm{mg} \cdot \mathrm{kg}^{-1}$ (P. abies) and $6.2-8.7 \mathrm{mgkg}^{-1}$ (P. omorika), manganese $129.0-161.3 \mathrm{mgkg}{ }^{-1}$ (P. abies) and $28.0-48.4 \mathrm{mg} \mathrm{kg}^{-1}$ (P. omorika), iron $113.7-189.2 \mathrm{mg} \mathrm{kg}^{-1}$ (P. abies) and 122.7-223.9 $\mathrm{mg}^{-1} \mathrm{~kg}^{-1}$ (P. omorika), and cadmium concentration range from 11.1 to $1.3 \mathrm{mgkg}^{-1}$ (P. abies) and 0.1-0.2 $\mathrm{mg} \cdot \mathrm{kg}^{-1}$ (P. omorika) (Tab. 3). The concentrations of the majority of heavy metals in the needles of the studied spruces were in the range of limit values, with the exception of nickel, which occurred in elevated quantities. The average content of zinc in the aboveground parts of the plants remained usually at the level of $10-70 \mathrm{mg} \cdot \mathrm{kg}^{-1}$, nickel was below $5 \mathrm{mg} \mathrm{kg}^{-1}$, copper ranged from 5 to $20 \mathrm{mg} \cdot \mathrm{kg}^{-1}$, iron below $375 \mathrm{mg} \cdot \mathrm{kg}^{-1}$, a manganese below $500 \mathrm{mg} \cdot \mathrm{kg}^{-1}$ (Kabata-Pendias and Pendias 1999). Cadmium, however, as a toxic metal, is accumulated by plants most often in a passive way (Baran and Jasiewicz 2009). The needles of P. abies tested by Wyttenbach and Tobler (1988) accumulated from 40 to $673 \mathrm{mg} \cdot \mathrm{kg}^{-1} \mathrm{Mn}$, depending on the tree stand and age of the needles. Subsequent studies by Wyttenbach and Tobler (2000) describe the accumulation of $\mathrm{Zn}$ in P. abies at the level of $11-51 \mathrm{mg} \cdot \mathrm{kg}^{-1}$, and $\mathrm{Fe}$ at the level of $12-65 \mathrm{mg}^{-1} \mathrm{~kg}^{-1}$.

In general, it was shown that $P$. abies needles accumulated larger amounts of phosphorus, potassium, manganese and cadmium, and P. omorika of nitrogen, magnesium, calcium, iron, zinc, nickel and copper. Relations between nutrients and heavy metals in needles were arranged in the following decreasing series, depending on the species and age of needles:

- Picea abies: $\mathrm{N}>\mathrm{K}>\mathrm{Ca}>\mathrm{P}>\mathrm{Mg}>\mathrm{Mn}>\mathrm{Fe}>\mathrm{Zn}$ $>\mathrm{Ni}>\mathrm{Cu}>\mathrm{Cd}$ (1-year-old needles)

- $\mathrm{N}>\mathrm{K}>\mathrm{Ca}>\mathrm{P}>\mathrm{Mg}>\mathrm{Fe}>\mathrm{Mn}>\mathrm{Zn}>\mathrm{Ni}>\mathrm{Cu}>$ Cd (2-year-old needles)

- Picea omorika: $\mathrm{N}>\mathrm{K}>\mathrm{Ca}>\mathrm{P}>\mathrm{Mg}>\mathrm{Fe}>\mathrm{Zn}>$ $\mathrm{Mn}>\mathrm{Ni}>\mathrm{Cu}>\mathrm{Cd}$ (1-year-old needles)
- $\mathrm{Ca}>\mathrm{K}>\mathrm{N}>\mathrm{P}>\mathrm{Mg}>\mathrm{Fe}>\mathrm{Zn}>\mathrm{Mn}>\mathrm{Ni}>\mathrm{Cu}>$ $\mathrm{Cd}$ (2-year-old needles)

In addition, statistically significant differences were found in the $\mathrm{N}, \mathrm{K}, \mathrm{Ca}, \mathrm{Zn}, \mathrm{Mn}, \mathrm{Fe}, \mathrm{Ni}, \mathrm{Cu}$ and $\mathrm{Cd}$ in 1-years old and in the $\mathrm{pH}, \mathrm{N}, \mathrm{P}, \mathrm{Ca}, \mathrm{Zn}, \mathrm{Mn}, \mathrm{Fe}$, $\mathrm{Ni}, \mathrm{Cu}$ and $\mathrm{Cd}$ in 2-years old P. abies and P. omorika (Tab. 3).

\section{Physicochemical properties of spruce bark}

The bark of trees is a very important and extremely sensitive indicator of environmental pollution (Sawids et al. 2011; Rungruang et al. 2016). Previous studies indicate that bark accumulation abilities depend on the species, age and health status of trees and the properties of the soil on which they grow. The physicochemical properties of the bark depend on the structure and associated porosity, which affect the retention of dusts and aerosols along with various elements in quantities proportional to its surface (Chrzan 2013). The results of our research indicate that the spruce bark was acidic, assuming $\mathrm{pH}$ values of 4.70 (P. abies) and 4.15 (P. omorika) (Tab. 4). According to literature data, the bark of most tree species is acidic and shows $\mathrm{pH}$ values ranging from 3.0 to 5.5 (Marmor and Randlane 2007; Parzych et al. 2017).

Table 4. Nutrients and heavy metals $\left(\mathrm{mg} \cdot \mathrm{kg}^{-1}\right)$ content and $\mathrm{pH}$ in bark of Picea species with U Mann Whitney test results

\begin{tabular}{|c|c|c|c|}
\hline $\begin{array}{c}\text { Para- } \\
\text { meter }\end{array}$ & $\begin{array}{c}\text { Picea } \\
\text { abies }\end{array}$ & $\begin{array}{c}\text { Picea } \\
\text { omorica }\end{array}$ & $\begin{array}{c}\text { U Mann Whitney } \\
\text { test }(\mathrm{p})\end{array}$ \\
\hline $\mathrm{pH}$ & $4.70 \pm 0.19$ & $4.15 \pm 0.15$ & $<0.05$ \\
\hline $\mathrm{N}$ & $592 \pm 52$ & $1625 \pm 55$ & $<0.05$ \\
\hline $\mathrm{P}$ & $23.7 \pm 6.7$ & $66.0 \pm 0.53$ & - \\
\hline $\mathrm{K}$ & $627.33 \pm 120.5$ & $3717.0 \pm 4420$ & $<0.05$ \\
\hline $\mathrm{Mg}$ & $670.43 \pm 37.0$ & $534.5 \pm 11.5$ & $<0.05$ \\
\hline $\mathrm{Ca}$ & $9763.0 \pm 175.1$ & $8104.0 \pm 118.3$ & $<0.05$ \\
\hline $\mathrm{Zn}$ & $100.37 \pm 0.78$ & $108.87 \pm 1.20$ & $<0.05$ \\
\hline $\mathrm{Ni}$ & $170.80 \pm 3.66$ & $41.77 \pm 3.81$ & $<0.05$ \\
\hline $\mathrm{Cu}$ & $7.73 \pm 0.45$ & $7.20 \pm 0.78$ & - \\
\hline $\mathrm{Mn}$ & $109.00 \pm 7.21$ & $18.67 \pm 5.03$ & $<0.05$ \\
\hline $\mathrm{Fe}$ & $414.60 \pm 3.10$ & $614.37 \pm 1.01$ & $<0.05$ \\
\hline $\mathrm{Cd}$ & $0.50 \pm 0.26$ & $1.50 \pm 0.23$ & - \\
\hline
\end{tabular}

The accumulation of chemical elements in the bark of trees, similar to $\mathrm{pH}$, strongly depends on the species 
and the influence of anthropogenic factors (Rykowska and Wasiak 2009). The obtained results indicate that the highest amounts of $\mathrm{Mg}, \mathrm{Ca}, \mathrm{Ni}, \mathrm{Cu}$ and $\mathrm{Mn}$ was accumulated in P. abies bark, while N, P, K, Zn, Fe and $\mathrm{Cd}$ in the bark of $P$. omorika (Tab. 4). This indicates that the bark of both the spruce species are suitable for comparative studies on bioindication of environmental. In addition, statistically significant differences were found in the $\mathrm{pH}$ and amount of accumulated $\mathrm{N}, \mathrm{K}, \mathrm{Ca}, \mathrm{Mg}, \mathrm{Zn}$, $\mathrm{Ni}, \mathrm{Mn}$ and $\mathrm{Fe}$ (Tab. 4). The source of origin of heavy metals in the bark of the studied spruces are mainly local sources of pollution, such as iron metallurgy, machinery and textile industry operating in Košice, as well as communication and transport (Rapport 2016).

\section{Conclusions}

Soil samples collected under the spruce tops showed different physicochemical properties depending on the species. Both at the sites of Picea abies and Picea omorika, soil was found to be acidulated under tree crowns and the acidification slightly changed with depth. Under the stand of P. abies, lower content of organic matter was demonstrated, than under the trees of P. omorika. The tested soil samples were low in N, $\mathrm{P}$ and $\mathrm{Ca}$ and sufficiently rich in $\mathrm{K}$ and $\mathrm{Mg}$. The spruce needles were dominated by macroelements, and their concentrations varied depending on age and species. Both $P$. abies and P. omorika needles were acidic, with 1-year-old needles showing higher acidity. The needles of $P$. abies accumulated larger quantities of $\mathrm{P}, \mathrm{K}, \mathrm{Mn}$ and $\mathrm{Cd}$, and the needles of P. omorika $-\mathrm{N}, \mathrm{Mg}, \mathrm{Ca}$, $\mathrm{Fe}, \mathrm{Zn}, \mathrm{Ni}$ and $\mathrm{Cu}$. A number of statistically significant differences in content of nutrients and heavy metals in 1-year-old and 2-year-old needles have been demonstrated. The results also indicate that the bark of the studied spruces was acidic, taking the values $\mathrm{pH}$ of 4.70 (P. abies) and 4.15 (P. omorika). P. abies bark accumulated higher amounts of $\mathrm{Mg}, \mathrm{Ca}, \mathrm{Ni}, \mathrm{Cu}$ and $\mathrm{Mn}$, and bark of P. omorika accumulated more N, P, K, Zn, Fe and $\mathrm{Cd}$. This indicates that the bark of both the spruce species are suitable for comparative studies in the field of environmental quality control. Statistically significant differences were found in the $\mathrm{pH}$ and amount of accumulated $\mathrm{N}, \mathrm{K}, \mathrm{Mg}, \mathrm{Ca}, \mathrm{Zn}, \mathrm{Ni}, \mathrm{Mn}$ and $\mathrm{Fe}$ in bark of the studies spruces.

\section{References}

Achat, D.L., Bakker, M.R., Augusto, L., Derrien, D., Gallegos, N., Lashchinskiy, N., Milin, S., Nikitich, P., Raudina, T., Rusalimova, O., Zeller, B., Barsukov, P. 2013. Phosphorus status of soils from contrasting forested ecosystems in southwestern Siberia: effects of microbiological and physicochemical properties. Biogeosciences, 10, 733-752.

Alloway, B.J. 1995. Soil processes and the behavior of metals. In: Heavy metals in soils. 2nd ed. (ed.: B.J. Alloway). Blackie, Glasgow, Great Britain, 7-28.

Augusto, L., Ranger, J., Binkley, D., Rothe, A. 2002. Impact of several common tree species of European temperate forests on soil fertility. Annals of Forest Science, 59, 233-253.

Baran, A., Jasiewicz, C. 2009. Toksyczna zawartość cynku i kadmu w glebie dla różnych gatunków roślin. Protection of the Environment and Natural Resources, 40, 157-164.

Bednarek, R., Dziadowiec, H., Pokojska, U., Prusinkiewicz, Z. 2005. Badania ekologiczno-gleboznawcze. PWN, Warszawa.

Bennet, J.P., Buchen, M.J. 1995. BIOLEFF three databases on air pollution effects on vegetation. Environmental Pollution, 88, 261-265.

Boratyńska, K. 2007. Geographic distribution. In: Biology and Ecology of Norway Spruce (eds.: M.G. Tjoelker, A. Boratyński, W. Bugała). Springer, Netherlands, 23-36.

Bugala, W. 2000. Drzewa i krzewy iglaste. PWRiL, Warszawa.

Cape, J.N., Freer, P.H., Paterson, I.S., Parkinson, J.A., Wolfenden, J. 1990. The nutrional status of Picea abies (L.) Karst. across Europe. Trees, 4, 211-224.

Chen, B., Stein, A., Castell, N., Gonzalez-Castanedo, Y., Sanchez de la Campa, A.M., de la Rosa, J.D. 2016. Modeling and evaluation of urban pollution events of atmospheric heavy metals from large $\mathrm{Cu}$-smelter. Science of the Total Environment, 539, $17-25$.

Chrzan, A. 2013. Zawartość wybranych metali ciężkich $\mathrm{w}$ glebie i korze sosny. Proceedings of ECOpole, 7 (2), 547-552.

Commission Advice Forest Fertilization. 1990. Final Report Commission Advice Forest fertilization. 
Report 1990-11. Ministry of Agriculture, Nature Conservation and Fishery.

Divan, A.M., Oliveira, P.L., Perry, C.T., Atz, V.L., Azzarini-Rostirola, L.N., Raya-Rodriguez, M.T. 2009. Using wild plant species as indicators for the accumulation of emissions from a thermal power plant, Candiota, South Brazil. Ecological Indicators, 9, 1156-1162.

Fober, H. 1993. Żywienie mineralne. In: Biologia sosny zwyczajnej (ed.: S. Białobok). Sorus, PoznańKórnik, 182-193.

Gonet, S.S. 2007. Ochrona zasobów materii organicznej gleb. In: Rola materii organicznej w środowisku (ed.: S.S. Gonet, M. Markiewicz). PTSH, Wrocław, 7-29.

Güsewell, S. 2004. N:P ratios in terrestrial plants: variation and functional significance. New Phytologist, 164, 243-266.

Jonczak, J., Parzych, A. 2012. Impact of Scots pine admixture European beech stand on the dissolved organic carbon and nitrogen leaching from organic and humic horizons of Dystric Arenosols in Northern Poland. Journal of Forest Science, 58 (6), 278-286.

Jonczak, J., Parzych, A. 2015. Comparing Empetro nigri-Pinetum and Vaccinio uliginosi-Betuletum pubescentis soils in terms of organic matter stocks and ecochemical indices in the Słowiński National Park. Forest Research Papers, 76 (4), 360-369.

Jonczak, J., Parzych, A. 2016. Properties of soil organic matter in soils of mid-forest spring niches in the Kamienna Creek valley (Middle Pomerania). Sylwan, 160 (2), 135-143.

Jonczak, J., Parzych, A., Sobisz, Z. 2015. Decomposition of four tree species leaf litters in headwater riparian forest. Baltic Forestry, 21, 1, 133- 143.

Jóźwiak, M., Kozłowski, R. 2008. Deposition of selected metals in the Świętokrzyskie Mountains and their influence on changes of soil pH. Ecological Chemistry and Engineering A, 15 (11), 1239- 1256.

Kabata-Pendias, A., Pendias, H. 1999. Biogeochemia pierwiastków śladowych. PWN, Warszawa.

Kebel, P., Koštálik, J. 2011. Geological and geomorphological characteristics of the area of Botanical Garden of PJŠU in Košice and the use of these data in botanical practice. Thaiszia - Journal of Botany, 21, 153-159.
Kowalkowski, A., Kopron, H. 2006. Dynamika wartości $\mathrm{pH}$ w przedziałach buforowości gleb w regeneracyjnych uprawach sosnowych w zasięgu emisji azotowej. Monitoring Środowiska Przyrodniczego, 7, 59-72.

Mahendrappa, M.K., Foster, N.W., Weetman, G.F., Krause, H.H. 1986. Nutrient cycling and availability in forest soils. Canadian Journal of Soil Science, $66,547-572$.

Mankovská, B. 2001. A study of nutrition and toxic elements in the Carpathian Mountain forests using foliar analysis of white fir (Abies alba Mill.), Norway spruce (Picea abies Karst.), beech (Fagus sylvatica L.) and humus. In: Plant nutrition. Food security and sustainability of agro-ecosystems through basic and applied research (eds.: W.J. Horst, M.K. Schenk, A. Bürkert, N. Claassen, H. Flessa, W.B. Frommer, H. Goldbach, H.-W. Olfs, V. Römheld, B. Sattelmacher, U. Schmidhalter, S. Schubert, N.V. Wirén, L. Wittenmayer), Springer, Dordrecht, 924-925.

Marmor, L., Randlane, T. 2007. Effects of road traffic on bark $\mathrm{pH}$ and epiphytic lichens in Tallinn. Folia Cryptogamica Estonica, 43, 23-37.

Mochnacký, S., 2001. Botanická záhrada Univerzity P.J. Šafárika v Košiciach. ES UPJŚ Košice.

Obmiński, Z. 1977. Ogólny zarys ekologii. In: Świerk pospolity, Picea abies (L,) Karst. Nasze Drzewa Leśne 5 (ed.: S. Białaobok). PWN, Warszawa-Poznań, 332-371.

Oren, R., Ellsworth, D.S., Johnsen, K.H., Philips, N., Ewers, B.E., Maier, C., Schäfer, K.V.R., McCarthy, H., Hendrey, G., McNulty, S.G., Katul, G.G. 2001. Soil fertility limits carbon sequestration by forest ecosystems in a $\mathrm{CO}_{2}$-enriched atmosphere. Nature, 411, 469-472.

Ostrowska, A., Porębska, G. 2002. Skład chemiczny roślin, jego interpretacja i wykorzystanie w ochronie środowiska. Instytut Ochrony Środowiska, Warsaw.

Päivärinta, J., Lodenius, M. 1994. Effect of acidification on metal uptake of Picea abies seedlings. Bulletin of Environmental Contamination and Toxicology, 52, 444-451.

Parzych, A. 2018. Macro- and micronutrients accumulation in needles of Scots pine on coniferous forest habitats. Sylwan, 162 (2), 127-137. 
Parzych, A., Jonczak, J. 2013. Content of heavy metals in needles of Scots pine (Pinus sylvestris L.) in selected of pine forest in the Słowiński National Park. Archives of Environmental Protection, 1, 39, 41-51.

Parzych, A., Jonczak, J. 2014. Pine needles (Pinus sylvestris L.) as bioindicators in the assessment of urban environmental contamination with heavy metals. Journal of Ecological Engineering, 15, 3, 29-38.

Parzych, A. Trojanowski, J. 2009. The structure and dynamics of litterfall in forest stands in the Słowiński National Park in 2003-2005. Forest Research Papers, 70 (1), 41-48.

Parzych, A., Trojanowski, J. 2011. The effect of abundance of litterfall on retention of nitrogen and phosphorus in organic horizons of forest soils in Słovinski National Park. Baltic Coastal Zone, 15, 67-83.

Parzych, A., Mochnacký, S., Sobisz, Z., Kurhaluk, N., Polláková, N. 2017. Accumulation of heavy metals in needles and bark of Pinus species. Folia Forestalia Polonica, Ser. A, Forestry, 59 (1), 34-44.

Piczak, K., Leśniewicz, A., Żyrnicki, W. 2003. Metal concentrations in deciduous tree leaves from urban areas in Poland. Environmental Monitoring Assessment, 86, 273-287.

Polláková, N., Šimanský, V., Ložek, O., Hanáčková, E., Candráková, E. 2015. The changes of nutrient and risk elements of top soil layers under canopy of different tree species and grassland in Arboretum Mlyňany, Slovakia. Folia Oecologica, 42, 1, 29-34.

Rapport 2016. Air pollution in the Slovak Republic. Ministry of Environment of the Slovak Republic. Slovak Hydrometeorological Institute, Bratyslava.

Rautio, P., Fürst, A., Stefan, K., Raitio, H., Bartels, U. 2010. Sampling and analysis of needles and leaves. 19 pp. Manual Part XII. [In]: Manual and methods and criteria for harmonized sampling, assessment, monitoring and analysis of the effects to air pollution on forests. UNECE ICP Forest Programme Coordinating Centre, Hamburg.

Roberntz, P., Linder, S. 1999. Effects of long-term $\mathrm{CO}_{2}$ enrichment and nutrient availability in Norway spruce. II. Foliar chemistry. Trees, 14 (1), 17-27.

Rykowska, I., Wasiak, W. 2009. Dystrybucja rtęci i metali ciężkich w korze drzew liściastych jako wskaź- nik skażenia środowiska. Gospodarka Odpadami Komunalnymi, 273-282.

Rungruang, J., Somporn, C., Angkhana, I., Munetsugu, K., Satake, K. 2016. Levels of road traffic heavy metals in tree bark layers of Cassia fistula tree. International Journal of Environmental Science and Development, 7 (5), 385-388.

Sawidis, T., Breuste, J., Mitrovic, M., Pavlovic, P., Tsigaridas, K. 2011. Trees as bioindicator of heavy metal pollution in three European cities. Environmental Pollution, 159, 12, 3560-3570.

Schmidt-Vogt, H. 1977. Die Fichte. I. Taxonomie, Verreitung, Morphologie, ökologie, Waldesellschaften. Parey, Hamburg u. Berlin.

Silkina, O.V., Vinokurova, R.I. 2009. Seasonal dynamics of chlorophyll and microelement content in developing conifer needles of Abies sibirica and Picea abies. Russian Journal of Plant Physiology, 56, 6, 780-786.

Swan, H.S.D. 1972. Foliar nutrient concentrations in Norway spruce as indicators of tree nutrient status and fertilizer requirement. Pulp and Paper Research Institute of Canada, Woodlands Rep., 40, $1-20$.

Świercz, A. 2006. Suitability of pine bark to evaluate pollution caused by cement-lime dust. Journal of Forest Science, 52, 93-98.

Świercz, A., Smorzewska, E., Bogdanowicz, M. 2014. State of scots pine needles epicuticular waxes and content of microelements in bioindication. Ecological Chemistry and Engineering A, 21 (3), 367-375.

Wyttenbach, A., Tobler, L. 1988. The seasonal variation of 20 elements in 1st and 2 nd year needles of Norway spruce, Picea abies (L.) Karst. Trees, 2, $52-64$.

Wyttenbach, A., Tobler, L. 2000. The concentrations of $\mathrm{Fe}, \mathrm{Zn}$ and $\mathrm{Co}$ in successive needle age classes of Norway spruce [Picea abies (L.) Karst.]. Trees, 14, 198-205.

Wyttenbach, A., Bajo, S., Bucher, J., Furrer V., Schleppi, P., Tobler, L. 1995a. The concentrations of Ca, $\mathrm{Sr}, \mathrm{Ba}$ and $\mathrm{Mn}$ in successive needle age classes of Norway spruce [Picea abies (L.) Karst.]. Trees, 10, 31-39.

Wyttenbach, A., Schleppi, P., Tobler, L., Bajo, S., Bucher, J. 1995b. Concentrations of nutritional and 
trace elements in needles of Norway spruce as functions of the needle age class. Plant and Soil, 168, 305-312.

Zhao, H., Shao, Y., Yin, Ch., Jiang, Y., Li, X. 2016. An index for estimating the potential metal pollution contribution to atmospheric particulate matter from road dust. Sciences of the Total Environment, 550, 167-175.

Zhiguo, X., Baixing, Y., He, Y., Changchum, S. 2007. Nutrient limitation and wetland botanical diversity in northeast China: can fertilization influence on species richness? Soil Science, 172, 1, 86-93. 